\title{
Possibilities to Reinvent Digital Journalism to Face the Challenges of the New Technological Times
}

\author{
Ricardo Uhry ${ }^{*}$, Kati Caetano \\ Postgraduate Program in Communication and Languages, University Tuiuti of Parana UTP, Curitiba, Brazil \\ Email address: \\ ricardo.uhry@utp.edu.br (R. Uhry),katicaetano@hotmail.com (K. Caetano) \\ ${ }^{*}$ Corresponding author
}

To cite this article:

Ricardo Uhry, Kati Caetano. Possibilities to Reinvent Digital Journalism to Face the Challenges of the New Technological Times. Communication and Linguistics Studies. Vol. 7, No. 3, 2021, pp. 49-56. doi: 10.11648/j.cls.20210703.12

Received: July 26, 2021; Accepted: August 6, 2021; Published: August 11, 2021

\begin{abstract}
Because it involves constant change, the new technological times bring challenges: in addition to the pandemic crisis that affects everyone, among the tensions is a disruptive scenario in which platforming, algorithms, and datafication have emerged, which are related to the abuse of corporations, to which is added the crisis of journalism, challenges that require digital reinvention. Other communication problems can be indicated in a map of the communicative relations that are established and in which issues such as misinformation, sensationalism, consumerism, and pessimism can be located, to which solution alternatives are proposed. At the same time that there is crisis, promising possibilities arise such as mobile journalism, data journalism, longform journalism, experimental journalism, and promising possibilities such as adaptive journalism, sustainable journalism, experiential journalism, in addition to experiments such as artistic journalism, among others that stand alongside the consolidated practices of high-tech journalism involving platforms, human-algorithm hybrid journalism, robotic and AI journalism, of which empirical examples stand out. It arrives at the issue of hyper mediations and, moving forward, reflects on the possibilities offered by public space, regulation, and an international contract for the Internet. The methodological approach is essayistic and based on bibliographic review, and uses, as sources of evidence of the empirical cases referred to, journalistic documentation online, available on the Web. Thus, seeking to face such tensions, the purpose of this paper is to focus on possibilities of reinventing journalism through promising practices that highlight digital technologies, examining journalistic robots, use of artificial intelligence, algorithms, and other journalistic practices. As a result, several promising possibilities for the reinvention of journalism can be highlighted: (i) journalistically innovating on the Web so that it becomes a public space that allows citizen communication; (ii) consolidating the international movement to sign an Internet principles contract that includes digital journalism; (iii) contributing to improving the experience of both the communicators and the enjoyment of the interlocutors, among other imaginative possibilities and consolidated practices. Seeking a tension between these positions, we consider focusing on promising experimental practices that emphasize digital technologies, examining journalist robots, algorithms, and other journalistic experimental practices. It follows that the challenge of reinvention is to develop communicators' critical digital skills and the ability to sensitize interlocutors to feel from the other's perspective. Digital journalism can make use of different possibilities to face the challenges in new times.
\end{abstract}

Keywords: Communication, Journalism, Digital, Possibilities, Reinvention

\section{Introduction}

The research requires a panoramic analysis of the problems of communication that can indicate problematic issues, which can be indicated in a "map of communicative relations", proposed by Uhry [1], of the relations that are established and in which disinformation, sensationalism, consumerism and pessimism can be located, for which solution alternatives are proposed: (I) regulation of communications is a necessity in the face of disinformation, distortions and the problems of the lack of public control; (II) a comprehensive vision of communication is what is proposed for all those involved in the communicational processes who can thus realize that disinformation is not the best path; (III) critical reception and interlocution seem to be 
the most adequate postures before the media, allowing critical reflection about the pessimistic bias and the purposes of the actions, especially when they foment violence; (IV) Internet as a new public space and can even convey on the Web an optimistic view instead of the hegemonic pessimism in the media; (V) counter-hegemonic forms of communication are demonstrations of social creativity and valorization of the community, a movement against the hegemonic posture of encouraging consumerism; (VI) citizen-consumer can be considered the engaged citizen, aware of the influence of the media in relation to his consumption and who seeks interlocution (VII) corporate citizen can be considered an ideal of those who believe that integrated and critical communication can go beyond sensationalism and economic goals, including social and environmental responsibility; (VIII) spirituality is a new value that can be the basis of communication relations that can become more comprehensive in the sense of giving spiritual meaning to relationships to go beyond materialism, consumerism and negativism, to awaken the essence of ourselves and our relationships.

Such a complex conception of the problem of communication can serve as a backdrop to examine other issues arising from the new technological times that bring so many innovations that so quickly affect mainly one of the ways of communicating, journalism, in many ways as will be seen below, and place it facing a disruptive crisis, to the point that there may be questions about whether there is a future of digital journalism.

Seeking to contextualize the issue, in Brazilian research, digital communication is one of the areas that has received the most attention. Based on the analysis of a decade of articles by the National Association of Graduate Programs in Communication (Compos), Mattos, Barros and Oliveira [2] identified research axes and highlighted the "complexity, historicity and magnitude of the transformations leveraged by technologies of Communication and Information", which they call "cybercultural", which is the "second most voluminous axis", with $21 \%$ of the total number of works. The researchers bring reflections on "social uses and forms of relationship based on technological devices", presenting a "plurality of views on cyber and/or digital communication and culture". The articles were classified into (i) social networks (typology and analysis), (ii) web communities, (iii) digital activism, (iv) cyberspace $\mathrm{x}$ physical space, (v) digital games, (vi) cybernetics and (vii) actor-network theory. If, on the one hand, the number of approaches indicates many possibilities, on the other hand, the articles reveal "a positive dimension of technologies, including a radical integration to technologies (techno philia)", suggesting a "little critical" analysis.

The small criticality in relation to digital communication suggests that training plays an important role, which Van Dijck [3] refers to: "The implementation of solid education in the media, not only to teach, is urgently needed, to code, but also to think critically." It should be noted that in the Compos classification there is no digital journalism, suggesting that the organizers of the meta-research curiously do not confer relevance to journalism.

On the other hand, at the Brazilian Society for Interdisciplinary Communication Studies (Intercom) there are web journalism and multimedia communication research groups (which covers digital content, technological convergence, communication and digital culture) and at the Brazilian Association for Journalism Research (SBPJor) there are tables on teaching, research and innovation in digital journalism, trends between journalism and digital technologies and journalistic convergence on the internet.

Thus, we have presented a contextualization of communication, in which we place digital journalism in the context of the crisis of journalism, mainly from the advent of new technological times, and there are still other tensions: the platformization, the algorithms, and the datafication, which are related to the abuse of corporations, among other challenges that require solutions and make us critically reflect on the possibility of reinventing journalism. The relevance of the research is so great that it involves the fundamental question of whether, in the face of new technological times, there is a future for digital journalism.

Given this, the purpose of the research is to focus on possibilities of reinventing journalism through promising practices that highlight digital technologies by examining journalistic robots, use of artificial intelligence, algorithms, and other journalistic practices. The research questions involve issues such as: (a) Can the challenges that new technological times bring be met with experimental and innovative journalistic practices? (b) Can these journalistic possibilities contribute to the reinvention of journalism in new technological times? (c) How to build a future for digital journalism?

\section{Challenges and Possibilities of Journalism}

\subsection{Challenges of Journalism}

Journalism faced the new technological times, which brought, in Christofoletti's [4] review, challenges that triggered a disruptive crisis, mainly due to: (i) free information on the web; (ii) arrival of new non-journalist competitors (youtuber, digital influencer and other amateurs) who post information on the Internet more quickly; (iii) arrival of technological platforms that became middlemen and broke the domain of news distribution; (iv) "laxing of the quality" of information because there is no verification of "content, relevance and authenticity" and because there is a waiver of "responsibility for what becomes public"; (v) "deviation from the civil service and renunciation of the social role in the communities".

In a panoramic perspective, Uhry [1] proposes a map in the form of axes to envision communicative relationships: (a) mediation that goes from communicators to audiences; (b) integration of the social to the market, which involve aspects and dimensions indicate problems such as: norms 
(political-legal) which are related to the problem of misinformation; resources (economic) that can be associated with sensationalism; values (cultural) related to consumerism; and imaginary (technological) associated to pessimism.

The Communicative Relations Map highlights problems that can be associated with the crisis in journalism and to which solution alternatives are proposed. However, the crisis also brings opportunities and imaginative possibilities that can allow the reinvention of journalism, although, at the same time, each one of them brings with it challenges to be implemented.

\subsection{Possibilities of Journalism}

The reinvention of the journalism of the future involves journalistic experiments in which imaginative possibilities are adopted, that is, the vanguard of journalistic practice and research in the field of communication is built. In journalism, the magazine Columbia Journalism Review [5] registered the "11 best experiments in journalism", highlighting aspects such as: storytelling in creative ways, experimenting with the challenge. The experiments will be highlighted below.

One author pointing out paths was Salaverría [6], who proposed seven trends that would make the journalism of the future: "1. Mobile journalism, 2. Data journalism, 3. Longform journalism, 4. Hi-tech journalism, 5. Viral journalism, 6. Global journalism and 7. Laboratory journalism", which are also referred to below and developed with examples of experimental journalistic practices.

\subsubsection{Mobile Journalism}

Mobile journalism would be or adapted to mobile platforms, cell phones, tablets, phablets, wearables, and other mobile devices connected to the Internet, with the implantation of responsive web design, for small screens. It is about exclusive publications developed for tablets, cell phones, with a native mobile concept. An experimental practice is Snapchat Discover that was highlighted as one of the " 11 best experiments" by Columbia Journalism Review. There is also viral journalism that occurs in blogs, which are launched to compete with social networks. Or when use Twitter to spread news, Facebook for videos, trying to offer viral content to social networks. Furthermore, digital contributed as globalized journalism, because with the Internet as borders are extinct and digital news has become global, for example the major world journals: BBC, Voice of America, The Economist, National Geographic, The New York Times, El País and others.

\subsubsection{Data Journalism}

Data journalism that is supported on data bases, completed with infographic visualization of information, with multiple digital technologies for the treatment and display of the data. The New York Times face of dice journalism a distinctive quality factor that in 2021 was featured as Pulitzer Prizes Journalism [7] "For a courageous, prescient and comprehensive coverage of the coronavirus pandemic." Also, Sigma Awards [8] "a competition to celebrate the best data journalism around the world" that awarded works as "at the epicenter" by Lupa Agency, among others.

\subsubsection{Longform Journalism}

Longform journalism is characterized by texts with more than 140 characters, literary reporting, narrative journalism, offering more space and with the possibility of exclusive publishing, for example The New York Times. A longform journalism experiment in succession to Narratively magazine, which chooses a different topic each week and publishes a related and detailed history per day, which was one of the "11 best experiments" from Columbia Journalism Review magazine.

\subsubsection{Experimental Journalism}

Experimental journalism can be experimental journalistic practices or through an innovation laboratory in the media, with an internal unit for experimentation and development of products and services, especially in the digital sphere. It is the areas of innovation that experiment with new narratives and languages to detect the best way to tell each story and is adopted by The New York Times, BBC and others. In addition to those already mentioned, among the "best experiments" in Columbia Journalism Review magazine are Quartz, Vox, Columbia Daily Tribune Neighborhoods, Nautilus, Buzz Feed News, Des Moines Register, The Skimm, Medium Design and Serial.

\section{Imaginative Possibilities of Reinventing Journalism}

To which one can add imaginative possibilities that can contribute to the reinvention of the journalism of the future, initially from the reflections that Christofoletti [4] proposes on "Where is the way out" for the crisis of journalism in the the new technological times and then, the starting from experimental journalistic practices and something from avant-garde literature.

\subsection{Adaptive Journalism}

Adaptive journalism is what implies that, to face disruptive scenarios, it is necessary to constantly adapt, which involves "resilience and resistance", that is, at the same time, flexibility in the face of change, and "tenacity, persistence and conviction" for implement without giving up an "editorial governance plan" that involves the editorial, administrative and "engagement and circulation" dimensions in order to mobilize only journalists, owners and readers, but also "other stakeholders" according to Christofoletti [4].

\subsection{Sustainable Journalism}

Sustainable journalism is what seeks to create innovative editorial proposals, develop, and apply new technologies, develop new languages and new ways of connecting with the public to build models that are editorially independent and economically sustainable. As for the issue of support, Cagé 
[9] proposes that the essential values of journalism be preserved, but that managerial decision-making is not conducted by those who finance the business. What presupposes that the funding is done through non-profit organizations, such as the Scott Trust Foundation, which maintains the British newspaper The Guardian, or in a participatory manner, through many shareholders, so that the control is democratized. Christofoletti [4] highlights those foundations "are guided by a public spirit distinct from the aggressiveness of companies eager for profitability at all costs".

\subsection{Promising Possibilities}

We consider focusing on some promising possibilities that highlight the convergence of digital technologies with journalism and data journalism and other experiments and possibilities. Among them, Longhi and Caetano [10] point out the open paths to a journalism in which they propose the "value-experience" - a search for a value in journalistic practice that can provide "experience of the reader/user as a user of content ". From the analysis of the newspapers Folha de S. Paulo, The New York and The Guardian, the authors suggest "that an instance manifests itself in the production and fruition of journalistic content that we can define as value-experience".

Therefore, innovative practices of digital journalism that have been presenting a combination of technology and creativity stand out, of which a possibility is proposed, to be researched, to be glimpsed: the experiential journalism that involves aspects such as audience participation, rewarding experimentation, development of sensitivity and aesthetic taste of readers, and in which it seeks to increase affective relations in relation to the news, either by the innovative experimentation sought in the journalistic practice, or by the experience provided to the reader as a user of sensitive, engaging and enriching digital journalistic experience. There is also another possibility: that of aesthetic journalism or artistic journalism, among others, besides the possibilities that arise with high technology.

\section{High Tech Journalism}

High tech journalism (hi-tech, robot-journalism) refers to news written by robots, videos recorded by drones, use of virtual reality. Like the Los Angeles Times that adopted automatic writing by algorithm program without human intervention. Associated Press AP uses algorithms to deliver 4400 news stories automatically, multiplying the news production capacity by ten and then splitting it into the next ones.

\subsection{Platform Journalism}

Analyzing the production of "saleable" sociality, which has become a hallmark of the "culture of connectivity", Van Dijck [3] reviews the transformation from "network society" to "society by platforms and algorithms", which requires a journalism adapted to platforms. There are possibilities to dismantle platforms and rebuild sociality and Van Dijck [3] refers to an "ecosystem of connected media that is tied to the algorithmic basis of society, surrounded by vertical integration and interoperability. There seems to be no way out, with connectivity it has become an ideology, which requires reflection on the quality of the online experience "manipulable and salable as platforms have grown" and started to be managed by corporations.

Van Dijck's "culture of connectivity" [3] has the following dimensions: (i) dating: not only generating and interpreting data for storage but integrating processes to offer increasingly personalized services and with greater commercial value; (ii) algorithms: sequence of programming instructions to transform data into results. Algorithmic dating's and mediations are interdependent and are related to the web platform. (iii) Infrastructure: central in the articulation of communication flows and practices in digital environments: Amazon - cloud storage; Google, Apple, Microsoft - operating systems; Google, Facebook and Microsoft - undersea cables. (iv) Business models: based on platforms that affect all areas of digital communication. Here we have a challenge because journalism can become dependent on platforms to circulate and remunerate its production, with automation of advertising processes. (v) Platform governance - a set of technical, political, legal and communicational mechanisms and practices that regulate the functioning of digital communication. (vi) Practices technological artifacts emerge in the tensions between practices and materiality. (vii) Affordances - understanding of how it happens between users and the possible uses of interfaces and their functionality, that is, how the action can be dated.

In item (iv) "business models" we have a challenge, because journalism can become dependent on platforms to circulate and remunerate its production, with automation of advertising processes.

Adapting digital journalism to the "age of connection" is quite a challenge. In reflections on online platforms, d'Andrea [11] also notes the "tendency to platform everything", with "generalized adoption of certain operating logics by the most different technological and media artifacts". These changes in digital communication can be better understood if approached in their relationship with data, affections and their online mediation. It is expected that they are "socially fairer, sustainable and balanced" and linked to the "tensioning and reconfiguration of exploration logic" and the articulation of the Big Five (Google, Facebook, Apple, Amazon, Microsoft) and other digital platforms, which constitutes a "political and ethical challenge."

\subsection{Human-algorithm Hybrid Journalism}

Human-algorithm hybrid journalism is a trend towards hybridization, combining the journalist and the use of algorithm. Diakopoulos [12] argues that "the age of news algorithms" can help make digital journalism productive, citing the case of the Associated Press AP, a 170-year-old news service, which uses data from structured and using 
algorithms, it started to produce ten times more news than it did. It is a "hybrid" system that combines algorithms with journalists in news routines and requires responsibility.

There is no doubt that algorithms radically transform journalism. Diakopoulos [12] shows that the media is increasingly using algorithms to increase the effectiveness and efficiency of various activities in the news value chain. People are the ones who put the algorithms in motion, "who design, develop, operate and manage them", who define, measure and sample data to feed and train algorithms" and which consume and are affected by algorithmic results and decisions". The interaction between algorithms and humans in news production is the focus of Diakopoulos [12], who reflects on: (i) human values in the design and use of algorithms; (ii) the change in journalistic practices that arise with algorithms and that are a combination of news production routines that rely on the contribution of algorithms to increase sustainability.

For Diakopoulos [12], hybrid journalism is the interaction between algorithms and humans in journalism, decisions are made and extract the potential to cross these two decision-making modes, that of humans and algorithms. The proposal is to break down editorial workflows into different types of tasks and analyze the susceptibility to automation. There are limitations to algorithmic approaches, and it is evident that there are key areas where human cognition will be crucial. "As the boundaries of what is possible to accomplish with automation, algorithms and hybrid systems continue to expand," but "human journalists still have a lot to add when it comes to complex communication, expert thinking and ethical judgment." This is also true for the design of hybrid workflows, which, for now, will most likely remain a human endeavor and represent a challenging field of innovation management.

Diakopoulos [12] refers to trial and error approaches: "iterative prototyping, development and testing by a variety of entrepreneurs, established organizations and research labs". Human hybridization with algorithms in journalism is increasing and analyzes how integration in algorithmic and human decision-making takes place in different journalistic contexts: journalistic data mining, automated content production, newsbots information agents and algorithms in news distribution.

The integration of machines and humans is more visible in automated content production, according to Diakopoulos [12]. While "algorithms allow for larger scale and faster, more accurate and personalized journalism that creates business opportunities for news agencies," they have limitations in terms of data contingencies and difficulties in combining human flexibility and reporting quality. Appropriately, collaboration is the way forward. This, in turn, will change editorial structures and processes. "As people interact with these systems, the nature of their skills, tasks, roles and jobs will necessarily evolve, likely to favor abstract thinking, creativity and problem solving."

Diakopoulos [12] exposes how algorithmic decision-making, which impacts on various social sectors, can be held responsible. It describes the evolutionary algorithms win, distinguishes different types of algorithmic liability histories, and suggests methods for discovering them. Obviously, algorithmic journalism also needs to be held accountable. After all, without ethics and public interest as a compass, journalism will lose people's trust. In this context, Diakopoulos advocates algorithmic transparency as an approach to the responsible use of algorithms in news media.

Diakopoulos [12] defends the underlying technologies, presents a wide variety of use cases, and summarizes the current state of algorithmic journalism, which is something that is rapidly evolving. "Of course, the future of algorithmic media will involve a co-evolution of technology, people and society." It remains to be seen how the hybridization of human and algorithmic decision-making will take place and how this will affect the quality and performance of journalism.

\subsection{Robotic and AI Journalism}

Robotic and AI journalism, journalist robots or newsbots, and artificial intelligence AI, which will soon be in all newsrooms. Already mentioned by Diakopoulos [12], the Associated Press AP not only uses algorithms, but also artificial intelligence AI. The Washington Post has had a newsbot added to its staff and other newspapers may also have. Newsbots do a professional job and will play an ever-increasing role in news production, as team savings can be the differentiator. In principle it does not seem to be good for journalists who will be forced to yield their expertise to precise, punctual, unpaid algorithms that are unflappable even under pressure.

In Brazil, we identified an experience developed in partnership by Brazilian universities (Federal University of Minas Gerais and University of São Paulo), that of the digital "journalist robots" that generate daily updated news on Twitter [13]: (i) robot "Corona Reporter" about Covid-19, based on data from official bodies of the Brazilian Government and the statistics website WorldoMeter and (ii) "Da Mata Reporter" robot on deforestation in the Amazon, from the database of Terra Brasilis.

There is also a project by Folha de S. Paulo newspaper [14], called "Voz Delas" (Their Voice) that uses monitoring tools (machine learning and artificial intelligence AI) to check the "representation of women in the various contents produced by the newspaper" and seeks to raise "How many women are heard, who they are, and where they need to have more space".

From our point of view, a relationship with the technique that is harmful to both society and nature in general is exhausted, according to Heidegger [14], which triggers, in addition to the negative effects of algorithmizing and transformation of everything into data, by platforms, movements that indicate an adjustment relationship between man and machine, aiming at greater expressiveness, efficiency of information and data communication. We take as a reference the postulates, albeit essayistic, by Ed Finn [15], which advocate the possibility of the relationship with algorithms to be more cooperative, highlighting their potential to give vent and concreteness to human creation in the sense of generating empathy and realizing relevant social actions. The 
empirical experimental practices referred to the journalist robots "Corona Repórter", "Da Mata Repórter", and the use of machine learning, artificial intelligence AI in the project "Voz Delas" (Their Voice) are interesting possibilities.

\section{Hyper Mediations}

In the same line of reasoning, we arrive at hyper mediations evoking Scolari [16] who proposes "a theory of interactive digital communication" that considers technology-culture-society relations, which he calls "hyper mediations" defined as "weave of processes of exchange, production and symbolic consumption that encompasses many technologically interconnected subjects, media and languages". What happens through digital supports, hypertext structures, collaborating users, high interactivity with the interface, collaborative models (wiki, blog, participatory platforms), confluence and tension between the reticular/collaborative and the massive and multimediality and convergence.

Scolari [16] reflects on "how these hyper mediations produce us", with the assumption that "technologies not only transform the world, but also influence the perception that individuals have of the world". From what stands out: (i) a new temporal-spatial subjectivity that emerges from the incorporation of mobile technologies into our daily life; (ii) change in the bases of knowledge and communication with digital technology; (iii) integration of contributions from semiotics, narratology, literature, philosophy of language and network theories; (iv) dialogues with theories of mass communication, cultural studies and cybercultures; (v) cultural production and distribution processes and the forms that media consumption is adopting; (vi) such processes take place in social relations that are marked by conflicts by the hegemony that cross society.

Thus, Scolari's ecosystem [16] considers the media as a system animated by contamination and conflicts over the occupation of communicational niches and the extensive application of the textual model in which technology users are seen as readers of texts that they cooperate in the construction of their meaning and co-evolve with technologies.

\section{Possibilities for the Public Space to Allow Citizen Communication}

From what stands out that it is not possible to give full emphasis only to digital technologies, it is necessary to glimpse an entire digital ecosystem that was briefly mentioned. There are countless possibilities of digital journalism and digital communication, such as connective networks, blogs and personal websites and others, which can even become a communication space against hegemonic, as there is no way for the corporations that dominate and control the platforms to seek to monetize everything that is published.

There are user movements that demand regulatory policy actions and some governments have sought to establish transparent rules for digital communication. For example, the United States of America sues Google for monopoly, just as Europe has also taken actions against the Big Five in defense of citizenship. Challenges may include the misuse of digital communication for data manipulation for political purposes, in the case of Cambridge Analytica/Facebook, or for economic purposes.

The lack of regulation of new digital technologies can be associated with disinformation practices, a concept that encompasses disinformation with a manipulative purpose, false news, and post-truth. Disinformation is also referred to as fake news, false news, defined as the factoids invented to appear as credible journalism and which are disseminated with the intention of influencing, shaping, distorting the perception of reality, manipulating, since false information is deliberately shared to cause damage.

This scenario requires not only a critical analysis of its effects, but it highlights the need to develop and value educational practices for clarification and access to information, whether formal or informal. Against, for example, the disinformation practices of Cambridge Analytica, which, with the collusion of Facebook and other platforms, invaded the privacy of millions of people and manipulated with political purpose, Kaiser [17] proposes: (i) to make every citizen a "digital literate" to avoid "unethical practices" and "protect our data"; (ii) support regulation of communication practices; (iii) encourage companies "to opt for ethics"; (iv) demand that those who "committed abuses of power" are held accountable; (v) question whether the negative news is true; 6) avoid sharing what incites hatred and fear.

Faced with these challenges, one of the trends that is needed is regulation in the face of misinformation problems that occur in digital communication and are also related to platforming and algorithms. In addition to the above, there is a trend of Internet empowerment, led by the World Wide Web Foundation [18] with more than 50 organizations, to define a contract of principles for the Web, which is being sewn worldwide and which foresees responsibilities for everyone those involved: 1st. Governments: (i) ensure Internet connectivity and availability; (ii) respect people's right to privacy. 2nd. Companies: (iii) make the Internet financially viable and accessible to all, without exclusions when using and shaping the Web; (iv) respect consumer privacy and personal data; (v) develop technologies that foster the best and contest the worst for humanity. 3rd. Citizens: (vi) be creators and contributors to the Web; (vii) develop communities that respect civil discourse and human dignity; (viii) fight for the Web to remain open and public for all, now and in the future.

\section{Conclusion}

In view of the above, to address this movement of articulation of technique and society, we examine its current state and some experimental and avant-garde imaginative possibilities aimed at the reinvention of journalism, which is implied in the process of interface between journalism and algorithms and other trends here summarized that, in a way, 
oppose the challenges initially indicated in a map of the communicative relations that are established and in which issues such as misinformation, sensationalism, consumerism and pessimism can be located. Reflecting on these issues and others mentioned, we suggest that they can be balanced with practical experiments that can contribute to the reinvention of journalism.

On the other hand, there are also contradictory perceptions about the web: there are those who view the Internet unfavorably because it makes it possible to give a voice to subjects, they consider unqualified to give an opinion and, on the other hand, others are dazzled by the utopia of having a virtual possibility that it can unite peoples on every face of the earth.

These are challenges and possibilities that are placed alongside tensions such as misinformation, related to false news, and the abusive performance of corporations through platforms and algorithms; to which is opposed the search to guarantee the public space with a view to citizenship through a web principles contract and other regulatory actions.

Thus, in addition to the pandemic crisis that affects everyone, among the tensions caused by the new technological times, there is a disruptive scenario in which platforming, algorithms and misinformation have emerged, which are related to corporate abuse, innovation, and news false. To this is added the crisis of journalism, which requires a reinvention that involves experimental imaginative possibilities.

In such a way, while there is a crisis, there are opportunities for the reinvention of journalism: (i) journalistically innovate in the digital medium so that the web becomes a public space that allows citizen communication; (ii) consolidate the international movement to sign an Internet principles contract that includes digital journalism; (iii) contribute to improve the experience of both the communicators and the enjoyment of the interlocutors, among other mentioned experimental imaginative possibilities.

We also consider focusing on promising strategies that emphasize digital technologies, examining journalist robots, algorithms, and other journalistic innovations. The challenge of journalistic reinvention is to develop critical digital skills and the ability to sensitize and feel from the perspective of the other. Certainly, digital journalism will face the different possibilities and challenges that arise in the new technological times.

Given the above, a question that returns in the final reflection is how can education contribute to the reinvention of digital journalism? Van Dijck [2] highlights the need to teach younger people "about forms of communication" and the search to promote "analytical skills", the development of "critical judgment". To which we dare add the ability to feel the problem from the perspective of the other, develop sensitivity and better situate conflicts.

Here we are faced with the possibility of reinventing journalism and, without being dazzled, reflect critically to better be able to face the different possibilities and challenges of the new technological times, among which experimental imaginative possibilities stood out.

\section{Acknowledgements}

The PhD student Ricardo Uhry has a scholarship from Coordenação de Aperfeiçoamento de Pessoal de Nível Superior (Capes) and is supervised by Professor Kati Caetano, whom he thanks. Both authors are grateful for the comments of professors Suzana Barbosa, Zaclis Veiga, and Fábio Witzki on the oral presentation at the thematic table "Reinventions of journalism in new times" at the 24th Research seminar, and at the 19th. Scientific Initiation Seminar at the University Tuiuti of Paraná, Brazil.

\section{References}

[1] Uhry, R. (2020). Comunicação na sociedade: I. Perspectiva panorâmica. Columbia, SC, USA: Independently Publ. KDP Amazon, 79-84.

[2] Mattos, M. Â., Barros, E. J. M. \& Oliveira, M. E. (2018). Metapesquisa em comunicação: o interacional e seu capital teórico nos textos da Compós. Porto Alegre: Sulina, 99-138.

[3] Van Dijck, J. (2019). La Cultura de la conectividade: uma história crítica de las redes sociales. Buenos Aires: Siglo Veintiuno Editores.

[4] Christofoletti, R. (2019). A crise do jornalismo tem solução? Barueri: Estação das letras e cores, 79-91.

[5] Columbia Journalism Review. (2015). The 11 best experiments in journalism. Columbia Journalism Review, may-jun, 2015. Available in: http://experiment.cjr.org. Accessed on July 20, 2021.

[6] Salaverría, R. (2015). Siete periodismos con futuro. In: Roitber, G.; Piccato, F. (Org.) Periodismo disruptivo: dilemas y estrategias para la innovación. Buenos Aires: La Crujía, 2015, p. 137-143.

[7] Pulitzer Prizes Journalism. (2021). Available in: https://www.pulitzer.org/prize-winners-by-year/2021. Accessed on July 20, 2021.

[8] Sigma Awards. (2021). Available in: https://sigmaawards.org/no-epicentro-at-the-epicenter/. Accessed on July 20, 2021.

[9] Cagé, J. (2015). Sauver les médias: capitalisme, financement participatif et democratie. Paris. Ed. du Seuil et La Republique de las idées, 213-214.

[10] Longhi, R. R. \& Caetano, K. (2019). Valor-experiência no contexto do jornalismo experiencial. Galaxia, São Paulo, n. 42, set.-dez. 2019, p. 82-95.

[11] D'Andrea, C. (2020). Pesquisando plataformas online: conceitos e métodos. Salvador EdUFBA, 25-68.

[12] Diakopoulos, N. (2019). Automating the news: how algorithms are rewriting the Media. Cambridge: Harvard University Press, 1-241.

[13] Twitter. (2021). Corona Repórter. Available in: https://twitter.com/CoronaReporter. Da Mata Repórter. Available in: https://twitter.com/DaMataReporter. Accessed on July 20, 2021. 
[14] Heidegger, M. (1980). La question de la technique. Essais et conferences. Paris: Gallimard.

[15] Finn, E. (2017). What algorithms want: imagination in the age of computing. Cambridge: MIT Press.

[16] Scolari, C. (2013). Hipermediaciones: elementos para una teoría de la comunicación digital interactiva. Barcelona: Ed. Gedisa, 116-292.
[17] Kaiser, B. (2020). Manipulados: como a Cambridge Analytica e o Facebook invadiram a privacidade de milhões e botaram a democracia em xeque. Rio de Janeiro: Harper Collins, 359-364.

[18] World Wide Web Foundation. (2021). Principles for a Contract for the Web. Available in: https://contractfortheweb.org/. Accessed on July 20, 2021. 